\title{
The development of simultaneous measurement of viral load and physical status for human papillomavirus 16 and 18 co-infection using multiplex quantitative polymerase chain reaction
}

\author{
PRINYA PRASONGDEE ${ }^{1,2}$, PATCHARAPORN TIPPAYAWAT ${ }^{1,3}$, TEMDUANG LIMPAIBOON $^{1}$, \\ CHANVIT LEELAYUWAT ${ }^{1}$, MOLIN WONGWATTANAKUL ${ }^{1}$ and PATCHAREE JEARANAIKOON ${ }^{1}$ \\ ${ }^{1}$ Center for Research and Development of Medical Diagnostic Laboratories, Faculty of Associated Medical \\ Sciences; ${ }^{2}$ Clinical Chemistry Unit of Srinagarind Hospital, Faculty of Medicine; ${ }^{3}$ Department of Clinical \\ Microbiology, Faculty of Associated Medical Sciences, Khon Kaen University, Khon Kaen 40002, Thailand
}

Received December 28, 2017; Accepted July 13, 2018

DOI: $10.3892 /$ ol.2018.9549

\begin{abstract}
Persistent infection with human papillomavirus (HPV) type 16 and 18 is known to be a major risk factor for cervical cancer. Increased prevalence of co-infection with these high-risk types has been observed in pre-cancerous and cancerous tissues. The determination of physical status and copy numbers of viruses is therefore useful in clinical settings. A simple multiplex quantitative polymerase chain reaction (qPCR) for HPV16/HPV18 co-infection in one tube reaction was established in the present study using TaqMan ${ }^{\circledR}$-based PCR for E2 and E6 viral DNA. The detection range was up to $10^{6}$ copies with $100 \%$ specificity and high precision ( $\mathrm{CV}$ of cycle time $<0.5 \%$ ). The analytical accuracy and robustness were verified by competitive assay using an unequal mixture of HPV16/HPV18 DNA. No significant effect was demonstrated when compared with the simplex qPCR. The detection of physical status was evaluated in cervical samples, including 5 pre-cancerous and 15 cancerous samples. No significant difference was observed between simplex and multiplex qPCR $(\mathrm{P}=0.372)$. In conclusion, the developed multiplex qPCR method successfully demonstrated the viral status of the common HPV types in one tube. This assay will facilitate viral assessment and monitoring of cervical cancer associated with HPV16 and HPV18 co-infection.
\end{abstract}

Correspondence to: Dr Patcharee Jearanaikoon, Center for Research and Development of Medical Diagnostic Laboratories, Faculty of Associated Medical Sciences, Khon Kaen University, Khon Kaen 40002, Thailand

E-mail: patjea@kku.ac.th

Abbreviations: CXCA, cervical cancer; HR-HPV, high risk human papillomavirus; qPCR, quantitative polymerase chain reaction; $\mathrm{CV}$, coefficient of variation

Key words: human papillomavirus type 16, human papillomavirus type 18 , multiplex TaqMan ${ }^{\circledR}$ polymerase chain reaction, co-infection, pre-cancerous state, cervical cancer

\section{Introduction}

Cervical cancer (CXCA) is the fourth leading cause of cancer-associated mortality among females worldwide (1). The majority of CXCA cases are associated with high risk human papillomavirus (HR-HPV) infection. Among HR-HPV, HPV16 and HPV18 account for $70 \%$ of all CXCA cases worldwide (1), including in Asian populations (2). Epidemiological data revealed an increase in multiple HPV infection from $10 \%$ of CXCA cases in 2005 (3) to 65\% in 2016 (3-5). However, these figures may reflect a higher sensitivity of detection, resulting in the co-infection of HPV16 and HPV18 being reported as the most common HR-HPV in Africa (6) and Asia (7), and specifically in Thailand (8), as 31.9, 20.8 and $27.8 \%$, respectively. An increased odds ratio of HPV16 and 18 co-infection compared with single infection was demonstrated by Chaturvedi et al (9) and Trottier et al (10), but the opposite results were reported by Salazar et al (11). These controversial findings implied that other viral parameters, not only HPV genotype, may serve important roles in disease progression.

The physical state of HPV infection occurs as one of two forms: An episomal or an integrated form. The episomal state involves the complete life cycle of viral replication in the infected host cells, whereas the integrated form involves integration of HPV DNA into the host DNA, a major genetic event leading to cervical carcinogenesis (12). Viral integration and viral load have previously been reported to be biomarkers for cancer with high-grade cervical lesions (13). Several methods have been used for the detection of integrated HPV, including polymerase chain reaction (PCR) (14), in situ hybridization $(15,16)$ and amplification of papillomavirus oncogene transcripts (APOT) (17). These are all qualitative measurements. Recently, we established a quantitative PCR of E2 and E6 genes to measure the viral load and physical status of HPV16 DNA in one tube (18). A ratio of E2/E6 gene of 1.0 is used to define the episomal form, while a decreased ratio (less than 1.0) indicates the integrated form, due to deletion of the E2 gene during viral integration. The present study demonstrated the benefit of using viral numbers and physical status as surrogate markers of cancer progression. 
To the best of our knowledge, the present study was the first to report the simultaneous measurement of 4 genes, E2 and E6 genes of HPV16 and HPV18, in a single tube. The development of multiplex qPCR in the present study provides a total coverage of $70 \%$ of HR-HPV-associated CXCA, including single and co-infection of HPV16 and HPV18. The analytical performance of the multiplex qPCR was evaluated in clinical samples, compared with simplex qPCR.

\section{Materials and methods}

Samples. A total of 20 cervical tissues harboring single or co-infection of HPV16 and HPV18 were collected from 5 pre-cancerous lesions (mean, $42.2 \pm 6.6$ years) and 15 cancerous lesions (mean, $49.5 \pm 13.7$ years). Samples were collected between 2002 and 2004 under written informed consents approved by the Ethical Committee of Khon Kaen University, Khon Kaen, Thailand (approval no. HE562296) and between 2013 and 2014 approved by the the Ubonratchathani Cancer Hospital, Ubon Ratchathani, Thailand (approval no. CE012/2013). DNA samples were extracted using a QIAamp Viral DNA kit (Qiagen GmbH, Hilden, Germany), according to the manufacturer's protocol. Extracted DNA was used for HPV16 and HPV18 screening by Nested Multiplex PCR, as previously described (19).

Cell culture. The human papillomavirus Caski and HeLa cell lines containing the integrated form of HPV16 (600 DNA copies per cell) and HPV18 (20-50 DNA copies per cell) were used as internal standard for determination of physical status of HPV16 and 18, respectively. HeLa cell line containing HPV18 and CaSki cell line containing HPV16 were used as HPV positive controls. Cells were cultured in $25 \mathrm{~cm}^{2}$ flasks at $37^{\circ} \mathrm{C}$ with $5 \% \mathrm{CO}_{2}$ in Dulbecco's Modified Eagle Medium high glucose (DMEM-HG) media supplemented with $10 \%$ fetal bovine serum and $1 \%$ penicillin-streptomycin (10,000 U/ml penicillin and $10 \mathrm{mg} / \mathrm{ml}$ streptomycin; all Invitrogen; Thermo Fisher Scientific, Inc., Waltham, MA, USA). At 70\% confluency, cells were trypsinized with $1 \mathrm{ml}$ of $1 \mathrm{X}$ trypsin-EDTA at $37^{\circ} \mathrm{C}$ for $5 \mathrm{~min}$. The cell pellets were collected and centrifuged at 2,000 rpm for $3 \mathrm{~min}$ and subsequently used for DNA extraction.

HPV16 and HPV18 integration status assay. Plasmids containing the whole genomes of HPV16, HPV18, HPV45 and HPV58 (PBR322 for HPV16 and HPV58, PGM4 for HPV18 and HPV45) were provided by Professor Pientong from the Department of Microbiology, Faculty of Medicine, Khon Kaen University. Purified recombinant plasmid copy numbers were estimated by a spectrophotometer concentration measurement (NanoDrop 2000; Thermo Fisher Scientific, Inc.). The DNA calculation formula was $6.02 \times 10^{23}$ (copies/mol) $\mathrm{xA}_{260}(\mathrm{ng} / \mathrm{ml}) /(\mathrm{DNA}$ length $\mathrm{x} 660)=$ copies $/ \mathrm{ml}$. Plasmid DNA was then diluted with sterile water to obtain between $10^{6}$ and $10^{2}$ copies, and was used to establish calibration curves for measuring E2 and E6 by multiplex qPCR using a TaqMan ${ }^{\circledR}$ probe assay (Bioneer Corporation, Daejeon, Korea). The oligonucleotide sequences of primers and probes were followed as previously described $(20,21)$, with modifications to the quencher and reporter fluorescent dyes (Table I). E2 and E6 DNA were amplified using a qPCR thermocycler (Exicycler ${ }^{\mathrm{TM}}$; Bioneer Corporation). Each $50 \mu 1$ reaction mixture contained a premix (AccuPower ${ }^{\circledR}$ DualStar ${ }^{\mathrm{TM}}$; Bioneer Corporation) with $0.4 \mu \mathrm{M}$ probes and primers. The PCR reaction was initiated at $95^{\circ} \mathrm{C}$ for $10 \mathrm{~min}$, followed by 40 cycles at $95^{\circ} \mathrm{C}$ for $15 \mathrm{sec}$ and $63^{\circ} \mathrm{C}$ for $60 \mathrm{sec}$. Reactions lacking DNA template were used as negative controls as previously described. Quantification of E2 and E6 genes were analyzed using the calibration curve plotted between the quantification cycle $(\mathrm{Cq})$ on the $\mathrm{x}$-axis and the logarithm of the standard copy number on the y-axis $\left(10^{2}-10^{6}\right.$ copies). Linear regression equations were estimated as indicated in Fig. 1. The obtained $\mathrm{Cq}$ from samples were used to calculate E2 and E6 copies from these equations. Amplification efficiency was determined from the slope of log-linear calibration curve $\left(10^{-1 / \text { slope }}-1\right)(22)$.

Optimization of temperature for multiplex qPCR. Multiplex qPCR temperature for HPV16 (E2 and E6 genes) and HPV18 (E2 and E6 genes) was optimized. A mixture of $10^{5}$ copies of plasmids containing the whole genomes of HPV16 and HPV18 was used to optimize the annealing temperature from 55 to $64^{\circ} \mathrm{C}$. The temperature that produced the lowest $\mathrm{Cq}$ was selected as the optimal annealing temperature.

\section{Evaluation of multiplex qPCR performances}

Multiplex $q P C R$ analytical range. Ten-fold dilutions of mixed HPV16 and HPV18 whole genomic DNA (from $10^{2}$ to $10^{6}$ copies) were used as templates for determining the analytical range.

Multiplex qPCR analytical imprecision. Within-run and between-run precision were each determined using low $\left(10^{3}\right.$ copies $)$ and high $\left(10^{6}\right.$ copies $)$ concentrations of whole genome HPV16 and HPV18 DNA mixtures.

Multiplex $q P C R$ analytical specificity. Cross-reactivity with two other HPV genotypes, HPV45 and HPV58, was tested. No fluorescent signal indicated a lack of cross-reaction, and uninfected HPV DNA was used as a negative control.

Competitive effect of HPV16 and HPV18 in multiplex qPCR. A mixture of unequal concentrations of HPV16 and HPV18 DNA (from $10^{3}$ to $10^{6}$ copies) was used to evaluate competitive effects in multiplex qPCR. E2 and E6 copies obtained from unequal HPV16 and HPV18 templates (test) were compared to those determined using a single template of HPV16 or HPV18 (control) by a paired t-test. No significant difference $(\mathrm{P}>0.05)$ indicated no competitive effect.

Evaluation of physical status using multiplex $q P C R$ in clinical samples. The cut-off value for an episomal form (complete E2 and E6 sequence) was first determined using plasmid DNA containing whole HPV16 and HPV18 genomes. The E2/E6 ratio was calculated by the $95 \%$ confidence interval (CI) and used to interpret physical status in clinical samples as previously described (18). To verify the accuracy of the multiplex qPCR of HPV16 and HPV18, $10^{5}$ copies of Caski and HeLa cells containing pure integrated HPV16 and HPV18, respectively, were prepared according to the DNA calculation 
Table I. Oligonucleotide sequences and TaqMan ${ }^{\circledR}$ probes used for amplification of E2 and E6 genes of HPV 16 and HPV18.

\begin{tabular}{|c|c|c|c|c|}
\hline HPV type & Name & Sequence $\left(5^{\prime}-3^{\prime}\right)$ & $\begin{array}{c}\text { Amplified } \\
\text { product } \\
\text { length (bp) }\end{array}$ & (Refs.) \\
\hline HPV16 & $\begin{array}{l}\text { HPV16 E2 Forward primer } \\
\text { HPV16 E2 Reverse primer } \\
\text { HPV16 E2 Probe } \\
\text { HPV16 E6 Forward primer } \\
\text { HPV16 E6 Reverse primer } \\
\text { HPV16 E6 gene Probe }\end{array}$ & $\begin{array}{l}\text { AACGAAGTATCCTCTCCTGAAATTATTAG } \\
\text { CCAAGGCGACGGCTTTG } \\
\text { (TAMRA)-CACCCCGCCGCGACCCATA-(BHQ) } \\
\text { GAGAACTGCAATGTTTCAGGACG } \\
\text { TGTATAGTTGTTTGCAGCTCTGTGC } \\
\text { (Texus red)-CAGGAGCGACCCAGAAAGTTACC } \\
\text { ACAGTT-(BHQ) }\end{array}$ & 81 & $\begin{array}{l}\text { Peitsaro et al, } \\
2002(20)\end{array}$ \\
\hline HPV18 & $\begin{array}{l}\text { HPV18 E2 Forward primer } \\
\text { HPV18 E2 Reverse primer } \\
\text { HPV18 E2 Probe } \\
\text { HPV18 E6 Forward primer } \\
\text { HPV18 E6 Reverse primer } \\
\text { HPV18 E6 Probe }\end{array}$ & $\begin{array}{l}\text { AGAAGCAGCATTGTGGACCT } \\
\text { GGTCGCTATGTTTTCGCAAT } \\
\text { (TeT)-TCAACC-CACTTCTCGGTGCAGC-(BHQ) } \\
\text { TCACAACATAGCTGGGCACT } \\
\text { CTTGTGTTTCTCTGCGTCGT } \\
\text { (FAM)-GCCATTCGTGCTGCAACCGA-(BHQ) }\end{array}$ & 167 & $\begin{array}{l}\text { Damay et al, } \\
2009(21)\end{array}$ \\
\hline
\end{tabular}

HPV, human papillomavirus; bp, base pairs.

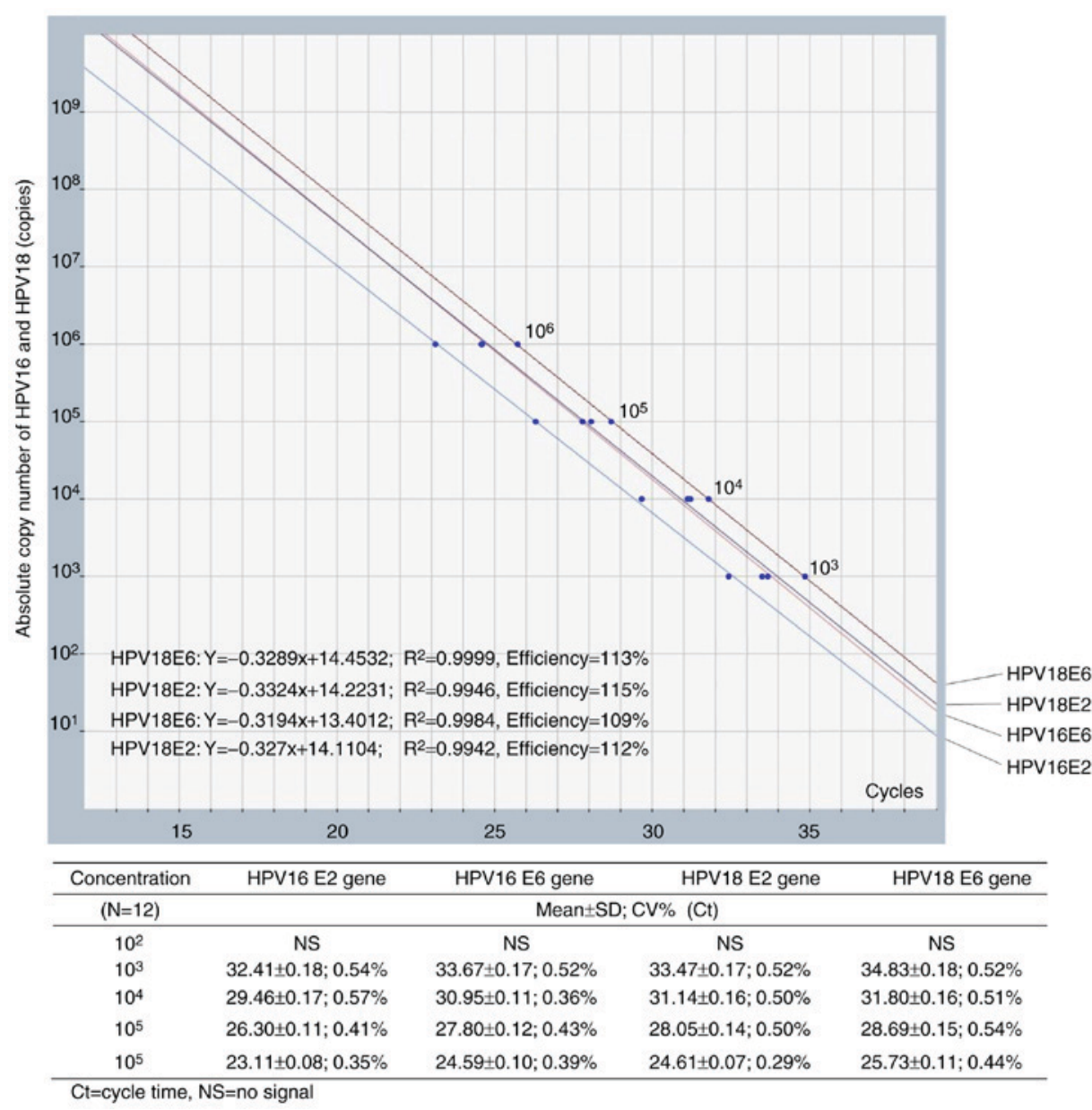

Figure 1. Standard curves of multiplex quantitative polymerase chain reaction for E2 and E6 genes of HPV16 and HPV18. The analytical range was revealed to be $10^{3}$ to $10^{6}$ copies. HPV, human papillomavirus; SD, standard deviation.

formula and used as internal standards for the integrated form. A total of $10^{5}$ copies of whole plasmid genome HPV16 
A

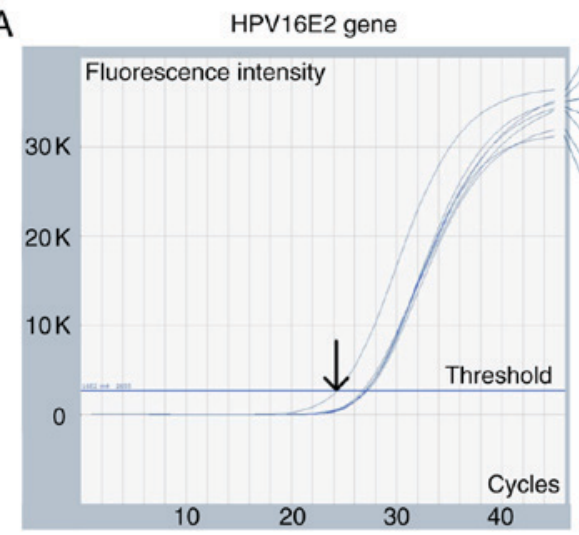

C

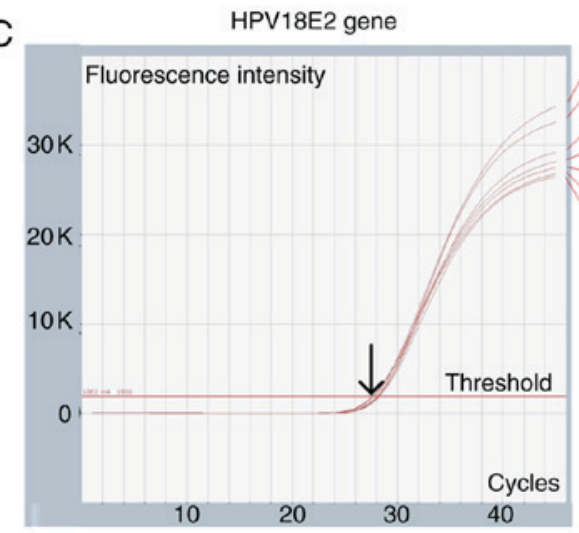

$B$
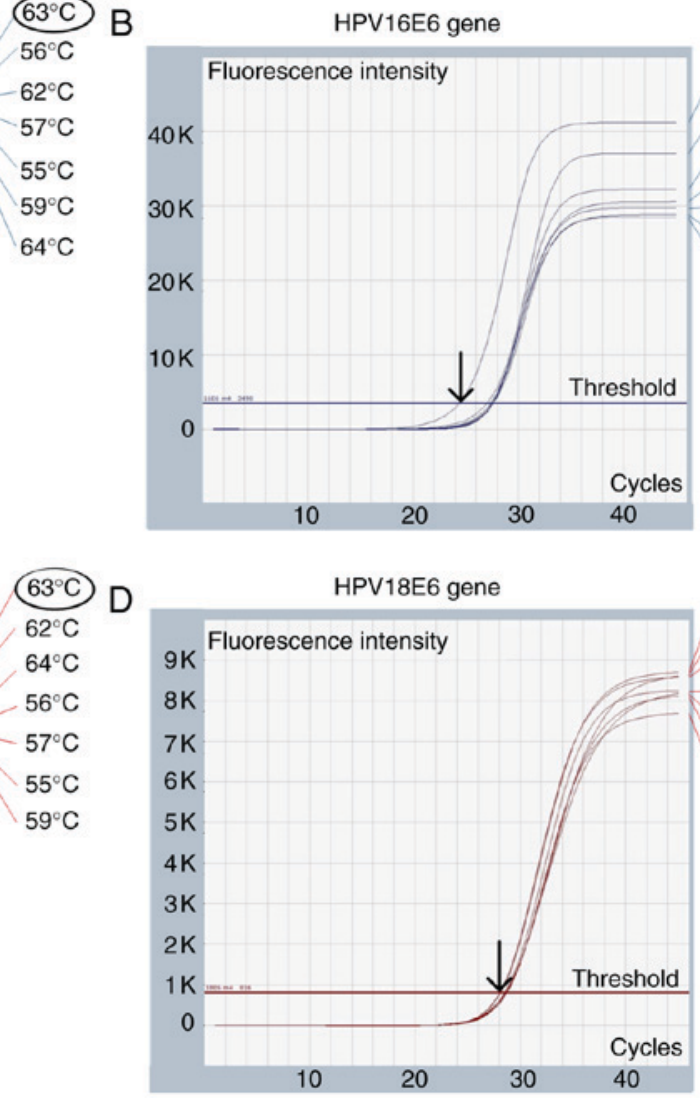

$63^{\circ} \mathrm{C}$

$62^{\circ} \mathrm{C}$

$64^{\circ} \mathrm{C}$

$56^{\circ} \mathrm{C}$

$57^{\circ} \mathrm{C}$

$55^{\circ} \mathrm{C}$

$59^{\circ} \mathrm{C}$

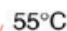

$56^{\circ} \mathrm{C}$

$62^{\circ} \mathrm{C}$

$57^{\circ} \mathrm{C}$

$64^{\circ} \mathrm{C}$

$63^{\circ} \mathrm{C}$

Figure 2. Optimization for (A) E2 and (B) E6 genes of HPV16, and (C) E2 and (D) E6 genes of HPV18. The optimal Cq for HPV16 and HPV18 was selected at $63^{\circ} \mathrm{C}$. HPV, human papillomavirus; Cq, quantification cycle.

and HPV18 were used as internal standards for the episomal form. The two cell lines were provided by Professor Pientong. A total of 20 cervical samples with single and mixed infection were used to compare the copy number and physical status between the simplex and multiplex qPCR using paired t-tests and $\chi^{2}$ tests.

Statistical analysis. The linear regression equation was estimated from standard curves between viral copy number (y-axis) and cycle time (x-axis). The percentage of efficiency between $80-120 \%$ and correlation $\left(\mathrm{R}^{2}\right)>0.98$ were used to determine the standard curve. The comparison of viral copy number between multiplex and simplex was performed using paired t-tests, while physical status was compared by $\chi^{2}$ test. $\mathrm{P}<0.05$ was considered to indicate a statistically significant difference. Statistical analysis was performed using SPSS 19 software (IBM Corp., Armonk, NY, USA) under a Khon Kaen University license.

\section{Results}

Multiplex qPCR performance for the detection of HPV16 and HPV18 (E2 and E6 genes). The optimization of $\mathrm{Cq}$ was performed under annealing temperatures from 55 to $64^{\circ} \mathrm{C}$, as demonstrated in Fig. 2. The optimal $\mathrm{Cq}$ for the E2 and E6 genes of HPV16 was $63^{\circ} \mathrm{C}$, whereas the optimal $\mathrm{Cq}$ for HPV18 was between 55 and $64^{\circ} \mathrm{C}$. Therefore, $63^{\circ} \mathrm{C}$ was used to construct a standard curve for HPV16 and HPV18 multiplex qPCR, as demonstrated in Fig. 1. According to the guidelines for validation of quantitative PCR methods, linear regression and correlation $\left(\mathrm{R}^{2}\right)$ analyses for each gene revealed an acceptable efficiency of $109-115 \%$ (23). The analytical range was verified at 1,000-1,000,000 copies for HPV16 and HPV18, with average imprecision from 0.42 to $0.50 \% \mathrm{CV}$ as demonstrated in Fig. 1. The imprecision of measured HPV copies is presented in Table II. The average CV of within-run and between-run was 10.2 and 12.1 , respectively. No cross reactivity was observed with HPV58 and HPV45 (Fig. 3).

Evaluation of competitive effect of unequal HPV16 and HPV18 template concentrations in multiplex qPCR. To mimic the presence of HPV16 and HPV18 co-infection up to 1,000-fold difference in the same sample, measurement of mixed HPV16 and HPV18 DNA was compared in parallel with that of single HPV16 and HPV18. Different concentrations of HPV16 and HPV18 exhibited no effect on the quantification of E2 $(\mathrm{P}=0.319$ and $\mathrm{P}=0.526$, respectively $)$ and $\mathrm{E} 6$ genes $(\mathrm{P}=0.347$ and $\mathrm{P}=0.146$, respectively), as demonstrated in Tables III and IV. Therefore, our established multiplex qPCR platform provided an accurate measurement for the presence of HPV16 and HPV18 co-infection.

Evaluation of physical status in clinical samples. Cut-off values for viral status were calculated as previously described by Wanram et al (18) and are shown in Table V. The E2/E6 ratio was identified as $0.78-1.10$ and $0.85-1.18$ for HPV16 
Table II. Analytical imprecision of the HPV16 (E2 and E6 genes) and HPV18 (E2 and E6 genes) measurement using multiplex quantitative polymerase chain reaction.

\begin{tabular}{|c|c|c|c|c|}
\hline \multirow[b]{2}{*}{ Precision } & \multicolumn{2}{|c|}{ HPV16 E2 gene } & \multicolumn{2}{|c|}{ HPV16 E6 gene } \\
\hline & $\begin{array}{c}\text { Mean } \pm \operatorname{SD}(\mathrm{CV} \%) \\
\mathrm{Cq}\end{array}$ & $\begin{array}{c}\text { Mean } \pm \mathrm{SD}(\mathrm{CV} \%) \\
\text { Copy number }\end{array}$ & $\begin{array}{c}\text { Mean } \pm \underset{C q}{\operatorname{SD}}(\mathrm{CV} \%) \\
\mathrm{Cq}\end{array}$ & $\begin{array}{c}\text { Mean } \pm \mathrm{SD}(\mathrm{CV} \%) \\
\text { Copy number }\end{array}$ \\
\hline \multicolumn{5}{|c|}{ Within-run $(\mathrm{n}=12)^{\mathrm{a}}$} \\
\hline Low level ${ }^{\mathrm{c}}$ & $32.41 \pm 0.18(0.54)$ & $961 \pm 127.1(13.23)$ & $33.67 \pm 0.17(0.52)$ & $1,084 \pm 149.1(13.74)$ \\
\hline High level $^{\mathrm{d}}$ & $23.11 \pm 0.08(0.35)$ & $952,490 \pm 59,040.35$ (6.19) & $24.59 \pm 0.10(0.39)$ & $1,097,119 \pm 81,784.1(7.45)$ \\
\hline \multicolumn{5}{|c|}{ Between-run $(n=15)^{b}$} \\
\hline Low level ${ }^{\mathrm{c}}$ & $32.61 \pm 0.20(0.60)$ & $973 \pm 141.36(14.53)$ & $34.26 \pm 0.19(0.54)$ & $929 \pm 137.45(14.79)$ \\
\hline \multirow[t]{2}{*}{ High level $^{\mathrm{d}}$} & $23.37 \pm 0.14(0.59)$ & $911,140 \pm 91,626.87(10.06)$ & $25.04 \pm 0.14(0.55)$ & $1,040,597 \pm 112,028.74(10.77)$ \\
\hline & \multicolumn{2}{|c|}{ HPV18 E2 gene } & \multicolumn{2}{|c|}{ HPV18 E6 gene } \\
\hline Precision & $\begin{array}{c}\text { Mean } \pm \text { SD }(\mathrm{CV}) \\
\mathrm{Cq}\end{array}$ & $\begin{array}{l}\text { Mean } \pm \text { SD }(\mathrm{CV}) \\
\text { Copy number }\end{array}$ & $\begin{array}{c}\text { Mean } \pm \text { SD }(\mathrm{CV}) \\
\mathrm{Cq}\end{array}$ & $\begin{array}{c}\text { Mean } \pm \text { SD }(\mathrm{CV}) \\
\text { Copy number }\end{array}$ \\
\hline \multicolumn{5}{|c|}{ Within-run $(\mathrm{n}=12)^{\mathrm{a}}$} \\
\hline Low level ${ }^{\mathrm{c}}$ & $33.47 \pm 0.17(0.52)$ & $1,159 \pm 160.1(13.81)$ & $34.83 \pm 0.18(0.52)$ & $1,067 \pm 144.35(13.52)$ \\
\hline High level $^{\mathrm{d}}$ & $24.61 \pm 0.07(0.29)$ & $1,123,790 \pm 60,126.32(5.4)$ & $25.73 \pm 0.11(0.44)$ & $1,023,242 \pm 86,472.54(8.45)$ \\
\hline \multicolumn{5}{|c|}{ Between-run $(n=15)^{b}$} \\
\hline Low level ${ }^{\mathrm{c}}$ & $34.03 \pm 0.19(0.57)$ & $996 \pm 147.1(14.76)$ & $34.77 \pm 0.19(0.53)$ & $958 \pm 134.18(14.00)$ \\
\hline High level $^{\mathrm{d}}$ & $25.00 \pm 0.11(0.43)$ & $992,011 \pm 81,890.14(8.25)$ & $25.42 \pm 0.13(0.51)$ & $1,054,498 \pm 101,053.01(9.58)$ \\
\hline
\end{tabular}

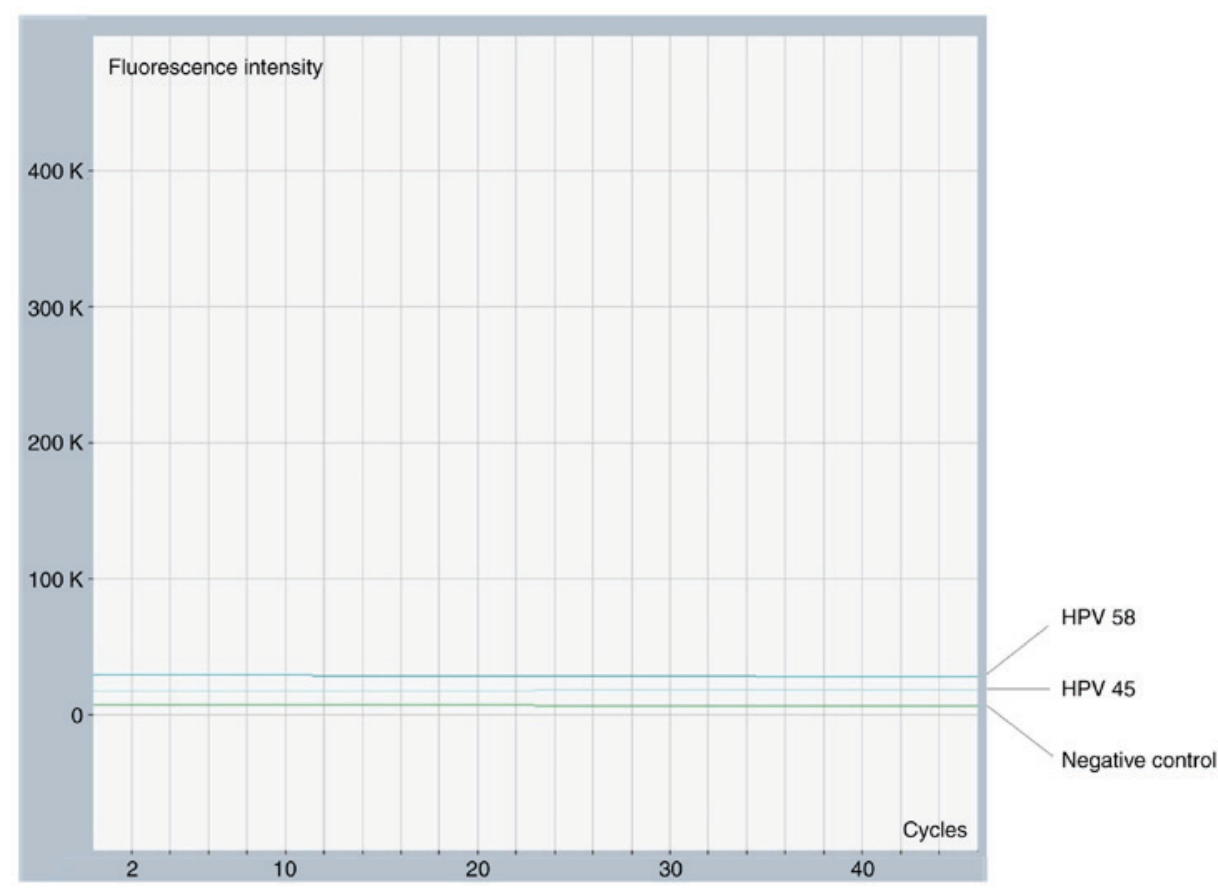

Figure 3. Analytical specificity of multiplex quantitative polymerase chain reaction. No cross reactivity was observed with $10^{4}$ copies of HPV45 and HPV58. Uninfected HPV DNA was used as a negative control. HPV, human papillomavirus.

and HPV18, respectively. An E2/E6 ratio of 0 was defined as the absolute integrated form, whereas E2/E6 $>0$ and less than the cut-off value was interpreted as the mixed form of episomal and integrated HPV (18). Comparisons of HPV16 


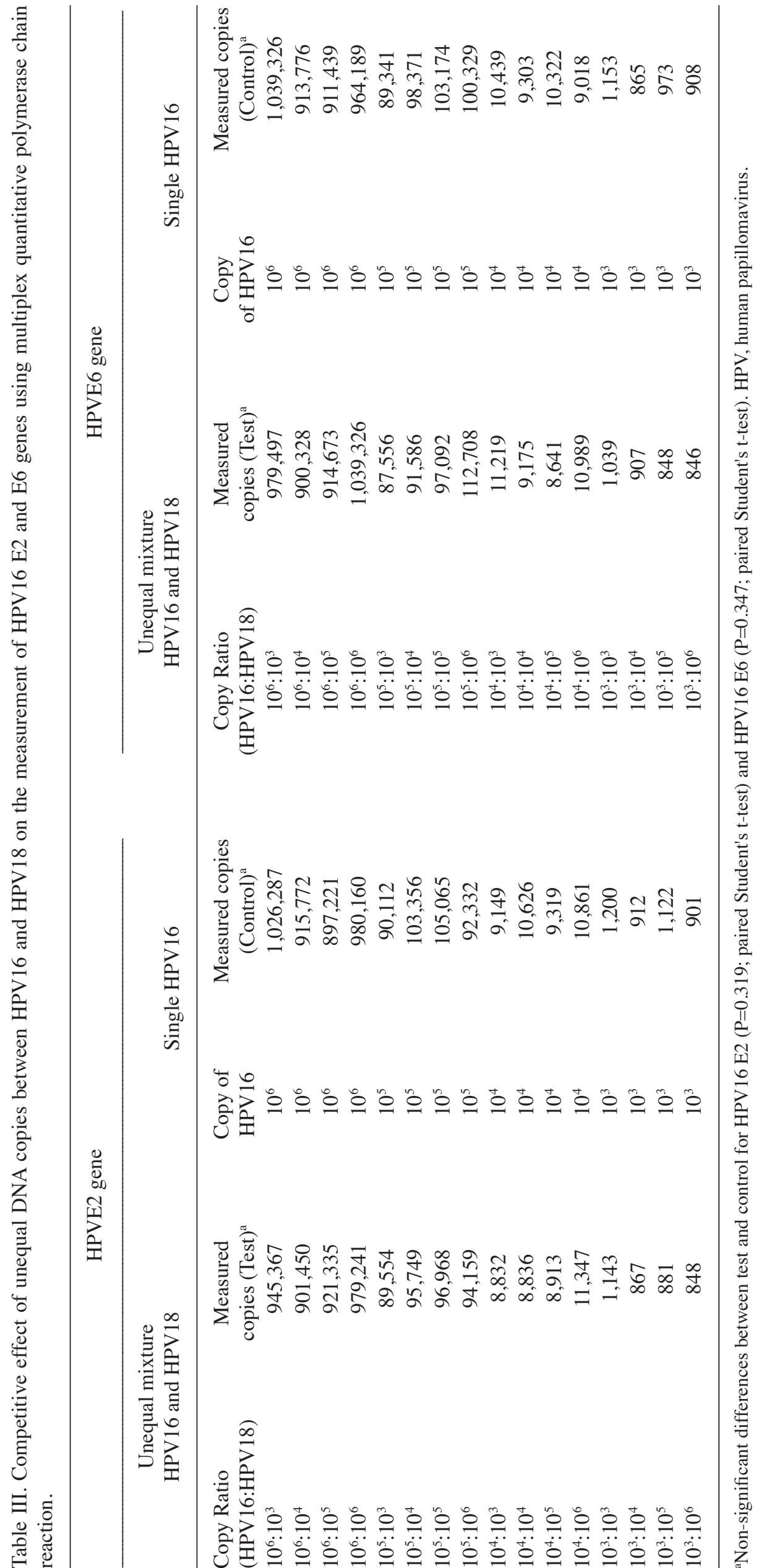




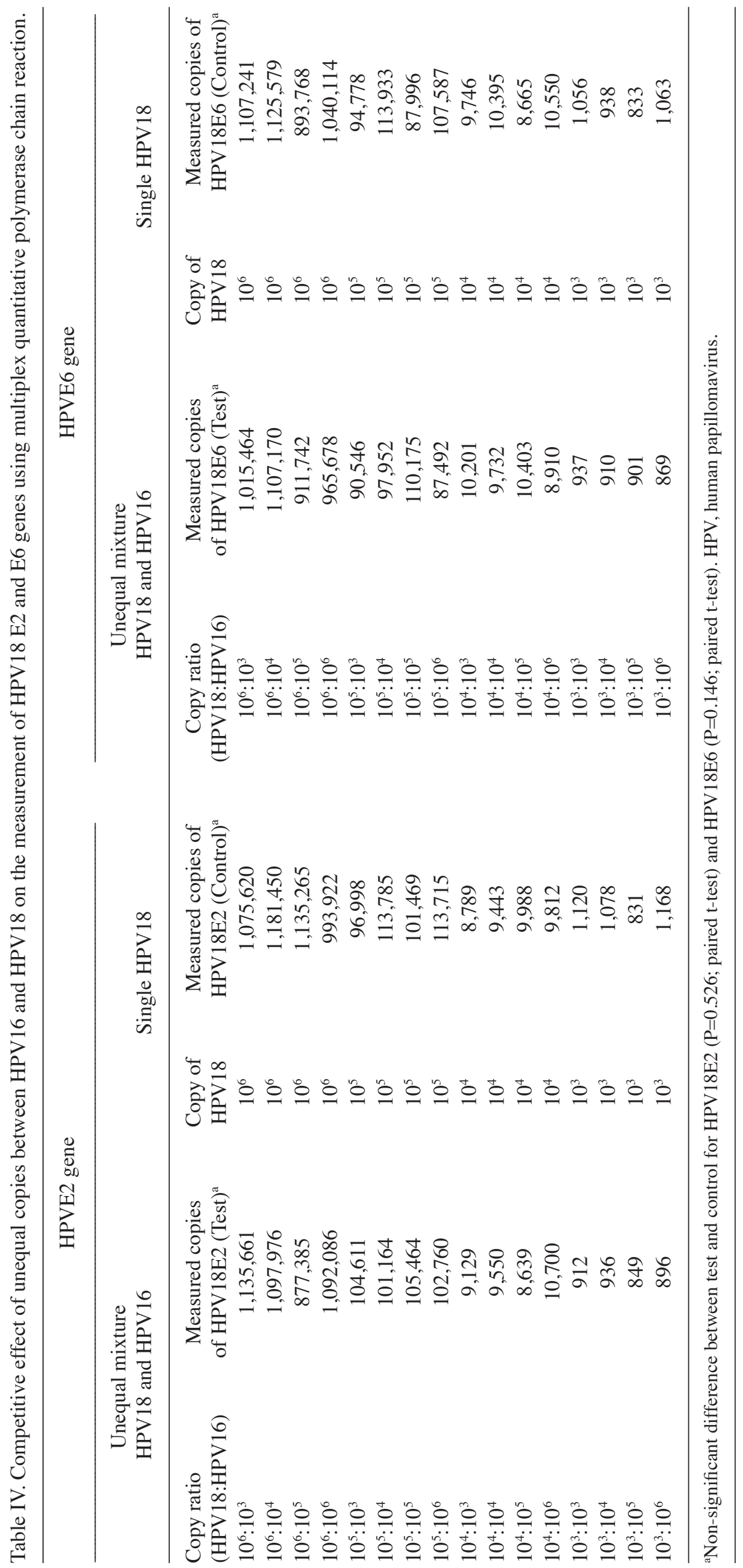


Table V. Estimation of cut-off values (E2 and E6 ratios) for the interpretation of physical status using various concentrations of whole genome plasmid DNA from $10^{4}$ to $10^{6}$ copies.

\begin{tabular}{|c|c|c|c|c|c|c|c|}
\hline \multirow[b]{2}{*}{ No. } & \multirow{2}{*}{$\begin{array}{l}\text { Mixture of equal } \\
\text { concentration of } \\
\text { HPV16 and HPV18 }\end{array}$} & \multicolumn{3}{|c|}{ HPV 16} & \multicolumn{3}{|c|}{ HPV18 } \\
\hline & & E2 gene (copy) & E6 gene (copy) & E2/E6 & E2 gene (copy) & E6 gene (copy) & E2/E6 \\
\hline 1 & $10^{3}$ & 1,115 & 1,103 & 1.01 & 1,153 & 1,233 & 0.94 \\
\hline 2 & $10^{3}$ & 1,115 & 1,185 & 0.94 & 1,019 & 1,210 & 0.84 \\
\hline 3 & $10^{3}$ & 908 & 1,044 & 0.87 & 1,193 & 1,211 & 0.99 \\
\hline 4 & $10^{3}$ & 1,168 & 1,169 & 1 & 1,155 & 1,134 & 1.02 \\
\hline 5 & $10^{3}$ & 1,038 & 1,047 & 0.99 & 1,146 & 1,179 & 0.97 \\
\hline 6 & $10^{4}$ & 8,882 & 10,814 & 0.82 & 10,760 & 9,858 & 1.09 \\
\hline 7 & $10^{4}$ & 8,789 & 10,438 & 0.84 & 9,187 & 9,408 & 0.98 \\
\hline 8 & $10^{4}$ & 9,019 & 10,379 & 0.87 & 8,703 & 9,062 & 0.96 \\
\hline 9 & $10^{4}$ & 9,233 & 9,268 & 1 & 8,513 & 8,220 & 1.04 \\
\hline 10 & $10^{4}$ & 9,117 & 9,337 & 0.98 & 9,687 & 11,622 & 0.83 \\
\hline 11 & $10^{5}$ & 94,603 & 105,819 & 0.89 & 110,462 & 107,970 & 1.02 \\
\hline 12 & $10^{5}$ & 108,055 & 108,928 & 0.99 & 107,699 & 102,882 & 1.05 \\
\hline 13 & $10^{5}$ & 88,246 & 100,449 & 0.88 & 106,389 & 98,269 & 1.08 \\
\hline 14 & $10^{5}$ & 87,938 & 105,370 & 0.83 & 114,166 & 112,276 & 1.02 \\
\hline 15 & $10^{5}$ & 106,246 & 100,978 & 1.05 & 109,971 & 113,442 & 0.97 \\
\hline 16 & $10^{6}$ & $1,098,531$ & $1,059,641$ & 1.04 & $1,086,195$ & 991,320 & 1.1 \\
\hline 17 & $10^{6}$ & 926,410 & 982,153 & 0.94 & $1,097,976$ & 996,524 & 1.1 \\
\hline 18 & $10^{6}$ & 912,783 & $1,076,185$ & 0.85 & $1,085,161$ & 927,645 & 1.17 \\
\hline 19 & $10^{6}$ & $1,020,080$ & 931,143 & 1.1 & $1,086,195$ & $1,005,826$ & 1.08 \\
\hline \multirow[t]{4}{*}{20} & $10^{6}$ & 940,240 & 997,234 & 0.94 & $1,146,435$ & $1,142,588$ & 1 \\
\hline & & & Mean & 0.94 & & Mean & 1.01 \\
\hline & & & SD & 0.08 & & SD & 0.08 \\
\hline & & & Mean \pm 2 SD & $0.78-1.10$ & & Mean \pm 2 SD & $0.85-1.18$ \\
\hline
\end{tabular}

HPV, human papillomavirus; SD, standard deviation.

and HPV18 copy numbers between the simplex and multiplex qPCR in CXCA samples are summarized in Table VI. No significant difference between simplex and multiplex qPCR was observed for HPV16 E2 and E6 $(\mathrm{P}=0.307$ and $\mathrm{P}=0.288$; paired t-test) and HPV18 E2 and E6 genes ( $\mathrm{P}=0.396$ and $\mathrm{P}=0252$; paired $\mathrm{t}$-test). The physical status obtained from multiplex qPCR was also compared with that from the simplex qPCR. The cut-off value for the episomal form of HPV16 (0.79-1.10) and HPV18 (0.85-1.18) was calculated as previously described for multiplex qPCR. Interpretation of physical status was similar in 95\% (19/20) of cases between multiplex and simplex qPCR assays, and differed in one case, $\mathrm{CX}-1\left(\mathrm{P}=0.372 ; \chi^{2}\right.$ test; Table VI).

\section{Discussion}

Multiple HR-HPV infection, particularly HPV16 and HPV18 co-infection, is now a concern due to its effects on cervical neoplasia development. The failure rate of treatment was previously reported to be increased by 5 -fold in multiple infection (57\%), compared with single infection (12\%) (24). Therefore, a suitable risk assessment among patients with persistent multiple HR-HPV infection is required. To assess the risk, viral load and viral physical status may be used for cancer prognosis. In the present study, a one tube qPCR assay for HPV16 and HPV18 co-infection was successfully established with acceptable performance in terms of specificity, accuracy and precision.

Upon performing a literature search for multiplex qPCR of 4 genes in one tube, one study by Zhao et al (25) was identified. The authors reported detection of 4 viral DNAs: HPV16 (E6 gene), HPV18 (E6 gene), HSV1 and HSV2, with an improved detection limit at 10 copies compared with the present study. The difference in the detection limit may result from the different size of viral DNA standard. Small fragments of viral DNA (66-139 bp) were used as standard in the study undertaken by Zhao et al, whereas the whole HPV genome (10728-12267 bp) was used in the present study. Accordingly, the small size template has an advantage for amplification when compared with the whole genome. Therefore, our established technique better represents the real viral infection in a clinical setting. To resolve this limitation, more DNA template may be adjusted. The accuracy of interpretation, including possible cross reactivity, was verified using DNA of known viral status from cervical Caski and HeLa cell lines. HPV58 and HPV45 were selected for cross reactivity according to 


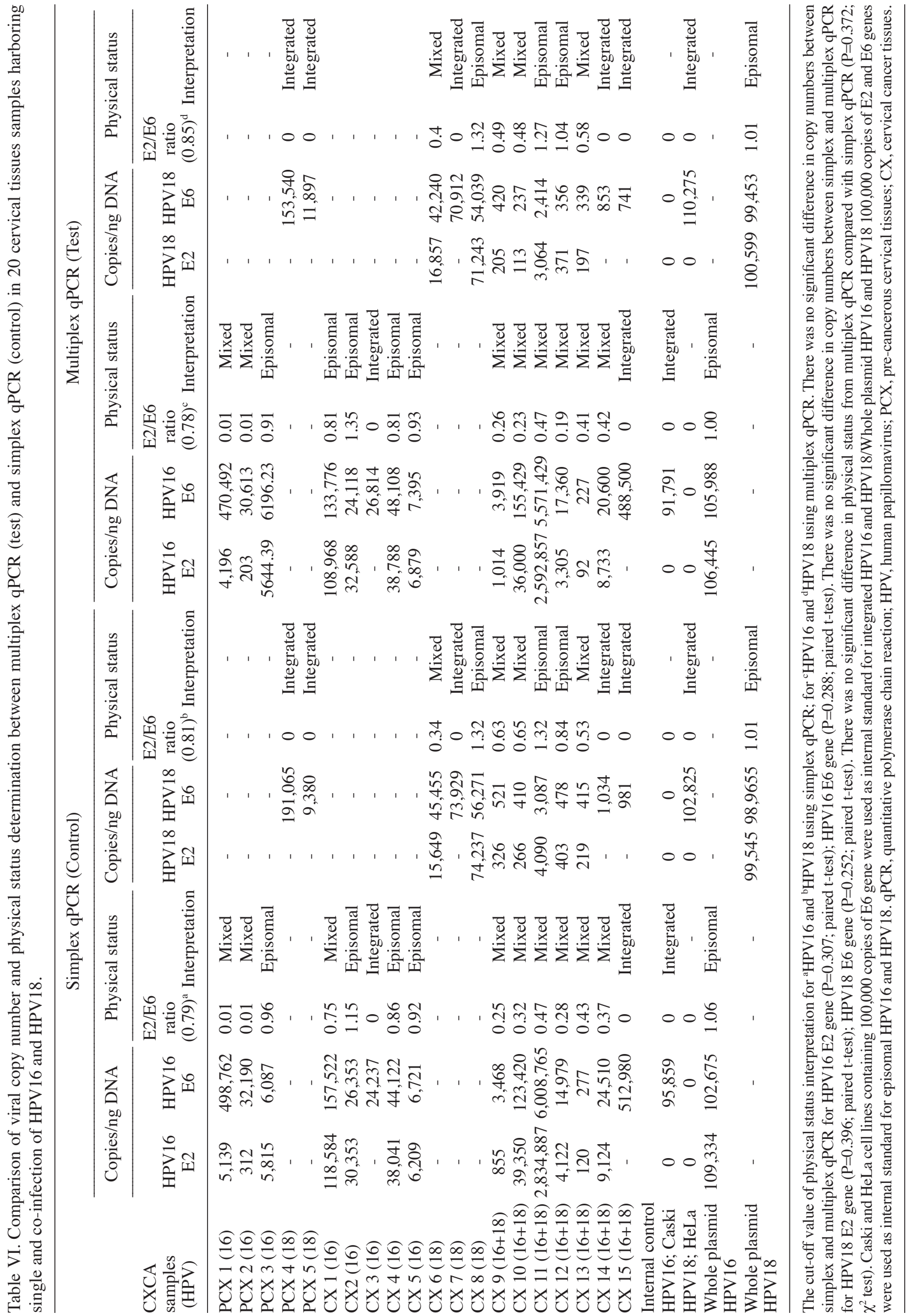


the top 4 common HR-HPV types (HPV 16, 18, 45 and 58), covering $90 \%$ of cases among Thai women (26). Accurate quantification was not only demonstrated via comparison with simplex qPCR, but it was also revealed that there was no competitive effect of an unequal mixed HPV DNA template from 10- to 1,000-fold (Tables III and IV).

Furthermore, the comparison of viral physical status between simplex and multiplex qPCR in clinical samples achieved 95\% (19/20 samples) agreement in the results of viral physical status. The different physical status of CX1 was caused by the variation of E2/E6 ratio between simplex (0.75) and multiplex (0.81) which closed to the cut-off value for episomal form (0.79 and 0.78$)$ resulting in discrepancy results as mixed form and episomal form, respectively. This limitation of accuracy occurred at values close to the cut-off values.

In conclusion, the increased incidence of HPV16 and HPV18 co-infection is a high-risk factor for CXCA progression in patients with persistent HR-HPV infection. Therefore, the successful development of multiplex qPCR for detecting HPV16 and HPV18 viral load and physical status in a single tube would provide a significant benefit in terms of cost effectiveness and shorter assay time in the clinic. To assess the potential of using this assay as a risk assessment for cancer progression in patients with single and co-infection with HPV16 and HPV18, a larger sample size with clinical outcome data should be included in future studies. In particular, pre-cancerous and early cancerous cases harboring high risk factors should be followed up frequently with monitoring of risk factors.

\section{Acknowledgements}

Clinical stage of samples were provided by Dr Metee Wongsena (Chief of Gynecologic Cancer Department, Ubonratchathani Cancer Center, Ubonratchathani, Thailand) and Dr Pissamai Yuenyao (Srinagarind Hospital, Khon Kaen, Thailand).

\section{Funding}

The present study was supported by the Targeted Research Fund of Khon Kaen University from the The National Research Council of Thailand (Khon Kaen, Thailand) and the Post-doctoral training program for MW (grant no. 58330) from the Graduate School of Khon Kaen University, Thailand.

\section{Availability of data and materials}

The datasets used and/or analyzed during the current study are available from the corresponding author on reasonable request.

\section{Authors' contributions}

PJ supervised, designed and assisted in the coordination of the present study. PP performed the research, the analysis and prepared data for the first draft of manuscript. TL and CL made substantial contributions in the conception and experimental design. MW was involved in data analysis, interpretation of data and drafting the final manuscript. PT assisted with data interpretation and revising the final manuscript. All authors have read and approved the final manuscript.

\section{Ethics approval and consent to participate}

The present study was approved by the Ethical Committee of Ubonratchathani Cancer Hospital (approval no. CE012/2013; Ubonratchathani, Thailand) and Khon Kaen University (approval no. HE562296; Kho Kaen, Thailand).

\section{Patient consent for publication}

All patients provided written informed consent for the publication of the present study.

\section{Competing interests}

The authors declare that they have no competing interests.

\section{References}

1. Bruni L, Barrionuevo-Rosas L, Albero G, Serrano B, Mena M, Gómez D, Muñoz J, Bosch FX and de Sanjosé S: ICO information centre on HPV and cancer (HPV Information Centre). Human papillomavirus and related diseases in the World. Summary Report 30 July 2017.

2. Bruni L, Barrionuevo-Rosas L, Albero G, Serrano B, Mena M, Gómez D, Muñoz J, Bosch FX and de Sanjosé S: ICO information centre on HPV and cancer (HPV Information Centre). Human papillomavirus and related diseases in Asia. Summary Report 27 July 2017.

3. Li N, Franceschi S, Howell-Jones R, Snijders PJ and Clifford GM: Human papillomavirus type distribution in 30,848 invasive cervical cancers worldwide: Variation by geographical region, histological type and year of publication. Int J Cancer 128: 927-935, 2011.

4. Wu EQ, Yu XH, Zha X, Zhang GN, Wang JH, Fan Y, Tang YY, Zhao ZX, Wu YG and Kong W: Distribution of human papillomavirus genotypes in archival cervical lesions in eastern inner Mongolian autonomous region. China Int J Gynecol Cancer 19: 919-923, 2009.

5. Youssef, MA, Abdelsalam L, Harfoush RA, Talaat IM, Elkattan E, Mohey A, Abdella RM, Farhan MS, Foad HA, Elsayed AM, et al: Prevalence of human papilloma virus (HPV) and its genotypes in cervical specimens of Egyptian women by linear array HPV genotyping test. Infect Agent Cancer 11: 1750-9378, 2016.

6. Téguété I, Dolo A, Sangare K, Sissoko A, Rochas M, Beseme S, Tounkara K, Yekta S, De Groot AS and Koita OA: Prevalence of HPV 16 and 18 and attitudes toward HPV vaccination trials in patients with cervical cancer in Mali. PLoS One 12: e0172661, 2017.

7. Siddiqa A, Zainab M, Qadri I, Bhatti MF and Parish JL: Prevalence and genotyping of high risk human papillomavirus in cervical cancer samples from Punjab, Pakistan. Viruses 6: 2762-2777, 2014

8. Suthipintawong C, Siriaunkgul S, Tungsinmunkong K, Pientong C, Ekalaksananan T, Karalak A, Kleebkaow P, Vinyuvat $S$, Triratanachat $S$, Khunamornpong $S$ and Chongsuwanich T: Human papilloma virus prevalence, genotype distribution, and pattern of infection in Thai women. Asian Pac J Cancer Prev 12: 853-856, 2011.

9. Chaturvedi AK, Katki HA, Hildesheim A, Rodríguez AC, Quint W, Schiffman M, Van Doorn LJ, Porras C, Wacholder S, Gonzalez P, et al: Human papillomavirus infection with multiple types: Pattern of coinfection and risk of cervical disease. J Infect Dis 203: 910-920, 2011.

10. Trottier H, Mahmud S, Costa MC, Sobrinho JP, Duarte-Franco E, Rohan TE, Ferenczy A, Villa LL and Franco EL: Human papillomavirus infections with multiple types and risk of cervical neoplasia. Cancer Epidemiol Biomark Prev 15: 1274-1280, 2006.

11. Salazar KL, Zhou HS, Xu J, Peterson LE, Schwartz MR, Mody DR and Ge Y: Multiple human papilloma virus infections and their impact on the development of high-risk cervical lesions. Acta Cytol 59: 391-398, 2015. 
12. Pett M and Coleman N: Integration of high-risk human papillomavirus: A key event in cervical carcinogenesis? J Pathol 212: 356-367, 2007.

13. Cricca M, Morselli-Labate AM, Venturoli S, Ambretti S, Gentilomi GA, Gallinella G, Costa S, Musiani M and Zerbini M: Viral DNA load, physical status and E2/E6 ratio as markers to grade HPV16 positive women for high-grade cervical lesions. Gynecol Oncol 106: 549-557, 2007.

14. Wu EQ, Zha X, Yu XH, Zhang GN, Wu YG, Fan Y, Ren Y, Kong LQ and Kong W: Profile of physical status and gene variation of human papillomavirus 58 genome in cervical cancer. J Gen Virol 90: 1229-1237, 2009.

15. Qureshi MN, Bolick D, Ringer PJ, Spagler FL and Zimmerman G: HPV testing in liquid cytology specimens: Comparison of analytic sensitivty and specificity for in situ hybridization and chemiluminescent nucleic acid testing. Acta Cytol 49: 120-126, 2005.

16. Fujii T, Masumoto N, Saito M, Hirao N, Niimi S, Mukai M, Ono A, Hayashi S, Kubushiro K, Sakai E, et al: Comparison between in situ hybridization and real-time PCR technique as a means of detecting the integrated form of human papillomavirus 16 in cervical neoplasia. Diagn Mol Pathol 14: 103-108, 2005.

17. Chaiwongkot A, Pientong C, Ekalaksananan T, Vinokurova S, Kongyingyoes B, Chumworathayi B, Patarapadungkit N, Siriaunkgul S and von Knebel Doeberitz M: Detection of the human papillomavirus 58 physical state using the amplification of papillomavirus oncogene transcripts assay. J Virol Methods 189: 290-298, 2013.

18. Wanram S,Limpaiboon T, Leelayuwat C, Yuenyao P, Guiney DG, Lulitanond V, Lulitanond V and Jearanaikoon P: The use of viral load as a surrogate marker in predicting disease progression for patients with early invasive cervical cancer with integrated human papillomavirus type 16. Am J Obstet Gynecol 201: 79.e1-e7, 2009.

19. Sotlar K, Diemer D, Dethleffs A, Hack Y, Stubner A, Vollmer N, Menton S, Menton M, Dietz K, Wallwiener D, et al: Detection and typing of human papillomavirus by E6 nested multiplex PCR. J Clin Microbiol 42: 3176-3184, 2004.

20. Peitsaro P, Johansson B and Syrjanen S: Integrated human papillomavirus type 16 is frequently found in cervical cancer precursors as demonstrated by a novel quantitative real-time PCR technique. J Clin Microbiol 40: 886-891, 2002.
21. Damay A, Didelot-Rousseau MN, Costes V, Konate I, Ouedraogo A, Nagot N, Foulongne V, Van de Perre P, Mayaud P and Segondy M: Viral load and physical status of human papillomavirus (HPV) 18 in cervical samples from female sex workers infected with HPV 18 in Burkina Faso. J Med Virol 81: 1786-1791, 2009.

22. Bustin SA, Benes V, Garson JA, Hellemans J, Huggett J, Kubista M, Mueller R, Nolan T, Pfaffl MW, Shipley GL, et al: The MIQE guidelines: Minimum information for publication of quantitative real-time PCR experiments. Clin Chem 55: 611-622, 2009.

23. Broeders S, Huber I, Grohmann L, Berben G, Taverniers I, Mazzara M, Roosens N and Morisset D: Guidelines for validation of qualitative real-time PCR methods. Trends Food Sci Technol 37: 115-126, 2014.

24. Munagala R, Donà MG, Rai SN, Jenson AB, Bala N, Ghim SJ and Gupta RC: Significance of multiple HPV infection in cervical cancer patients and its impact on treatment response. Int J Oncol 34: 263-271, 2009.

25. Zhao Y, Cao X, Tang J, Zhou L, Gao Y, Wang J, Zheng Y, Yin $S$ and Wang Y: A novel multiplex real-time PCR assay for the detection and quantification of HPV16/18 and HSV1/2 in cervical cancer screening, Mol Cell Probes 26: 66-72, 2012.

26. Bruni L, Barrionuevo-Rosas L, Albero G, Serrano B, Mena M, Gómez D, Muñoz J, Bosch FX and de Sanjosé S: ICO Information Centre on HPV and Cancer (HPV information centre). Human papillomavirus and related diseases in Thailand. Summary Report 27 July 2017.

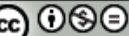

This work is licensed under a Creative Commons Attribution-NonCommercial-NoDerivatives 4.0 International (CC BY-NC-ND 4.0) License. 